nephron

Practice
Nephron 2019;141:49

DOI: $10.1159 / 000494510$
Received: October 5, 2018

Accepted: October 15, 2018

Published online: November 9, 2018

\title{
Nephrological Care Extended to Immigrants
}

\author{
Gioacchino Li Cavoli Rosanna Turdo Tancredi Vincenzo Li Cavoli \\ Department of Nephrology Dialysis Renal Transplant, Civico and Di Cristina Hospital Palermo Italy, Palermo, Italy
}

\section{Dear Editor}

We read with interest Prof. Bleyer's article [1] on nephrological care extended to immigrants; we here report our experience. In the Mediterranean Area, undocumented migration is a public policy problem [2-3]. In Italy, as in other countries, caring for undocumented dialysis immigrants is a public health issue [4]. Within its borders, the Italian health care system provides equal access to all individuals, regardless of legal immigration status. Italian law 449/1997 regulates health care for non-EU foreign citizens affected by serious diseases coming from countries without access to the necessary therapy or these countries with humanitarian crises due to political events or war. The Italian legislation establishes the same possibilities of access to organ transplantation, both for Italian citizens and individuals

\section{References}

1 Bleyer AJ: Office visit: kidney transplantation of a dreamer. Nephron 2018;139:283-285.

2 The Lancet Public Health: No public health without migrant health. Lancet Public Health 2018;3:e259. with legal immigration status. The Italian health system provides nephrological care to undocumented immigrants with kidney failure both in life-threatening situations through emergency hemodialysis and in chronic long-term dialysis status through non-emergency hemodialysis. These undocumented dialysis-dependent patients have the right to apply for a residence permit for humanitarian reasons, the right to register to Regional Health Services, and receive all health benefits as Italian citizens. According to existing laws, these dialysis foreign citizens with legal immigration status are allowed to be kidney transplant wait-listed, regardless of citizenship or ability to pay. According to Lazio (central-Italy region) Dialysis and Transplantation Registry, in the period between 2004 and 2012, among 4,076 pa- tients on chronic hemodialysis, health status and treatment of ESRD, including access to kidney transplantation, were similar between groups of Italian and foreign patients [5]. According to our experience in Sicily, in the Mediterranean Area, we did not observe less possibility to access dialysis treatment or renal transplant among immigrant population. WHO defines basic health care as a fundamental human right. Italian legislation provides to immigrant subjects the same opportunities to access dialysis and renal transplant.

\section{Disclosure Statement}

The authors have no conflicts of interest to declare.
3 Kentikelenis AE, Shriwise A: International organizations and migrant health in Europe. Public Health Rev 2016 Oct 20;37:19.

4 Linden EA, Cano J, Coritsidis GN: Kidney transplantation in undocumented immigrants with ESRD: a policy whose time has come? Am J Kidney Dis 2012;60:354-359.
5 Di Napoli A, Lapucci E, Baglio G, Di Giulio S; Registro Regionale Dialisi e Trapianto del Lazio: [Lazio dialysis registry: natives vs foreigners]. G Ital Nefrol 2015; 32:pii.

\section{KARGER}

(c) 2018 S. Karger AG, Basel

E-Mail karger@karger.com

www.karger.com/nef
Gioacchino Li Cavoli

Department of Nephrology Dialysis Renal Transplant Civico and Di Cristina Hospital Palermo Italy

Via Francesco Cilea 43, IT-90144 Palermo (Italy)

E-Mail gioacchinolicavoli@ libero.it 